\title{
Effects of aerated and non-aerated biofilters on effluent water treatment from a small-scale recirculating aquaculture system for Nile tilapia (Oreochromis niloticus L.)
}

\section{Auswirkungen aerober und anaerober Biofilter auf die Wasserqualität in einer kleindimensionierten Kreislaufanlage für Niltilapien (Oreochromis niloticus L.)}

\author{
Zipporah Gichana ${ }^{1 *}$, David Liti ${ }^{2}$, Silke-Silvia Drexler ${ }^{1}$, Werner Zollitsch ${ }^{3}$, Paul Meulenbroek ${ }^{1}$, Joseph Wakibia ${ }^{4}$, \\ Erick Ogello ${ }^{5}$, Peter Akoll ${ }^{6}$, Herwig Waidbacher ${ }^{1}$
}

\footnotetext{
${ }^{1}$ Institute of Hydrobiology and Aquatic Ecosystem Management, University of Natural Resources and Life Sciences, Gregor-Mendel-Straße 33, 1180 Vienna, Austria

2 Department of Biological Sciences, University of Eldoret, P. O. Box 1125-30100 Eldoret, Kenya

${ }^{3}$ Centre for Global Change and Sustainability, Division of Livestock Sciences, University of Natural Resources and Life Sciences (BOKU), Gregor-Mendel-Straße 331180 Vienna, Austria

${ }^{4}$ Department of Botany Jomo Kenyatta University of Agriculture and Technology, P.O. Box 62000 - 00200, Nairobi, Kenya

${ }^{5}$ Department of Fisheries and Natural Resources, Maseno University, Private Bag, Maseno, Kenya

${ }^{6}$ Department of Zoology, Entomology and Fisheries Sciences, Makerere University, P.O. Box 7062, Kampala, Uganda

* Corresponding Author: zippmoraa@yahoo.co.uk
}

Received: 3 April 2019, received in revised form: 17 August 2019, accepted: 17 September 2019

\begin{abstract}
Summary
Most recirculation aquaculture systems (RAS) use aerated biofilters to maintain suitable water quality for fish production. However, application of non-aerated biofilters may provide opportunities to lower aeration costs, water usage and concentration of all nitrogenous wastes in the effluent water. Our study aimed at comparing the biofiltration performance characteristics of two biofilters: a conventional aerated biofilter and a non-aerated biofilter receiving the same effluent water from a small-scale RAS. The two biofilters were evaluated in triplicate and tested concurrently for seven months. Water quality parameters were monitored at the biofilter inlets and outlets and in the fish tanks. At the beginning of the experiment, the concentration of ammonia at the two biofilter outlets were not significantly different. However, the concentrations decreased with time reaching mean values of $1.33 \pm 0.02 \mathrm{mg} \mathrm{L}^{-1}$ and $1.23 \pm$ $0.21 \mathrm{mg} \mathrm{L}^{-1} \mathrm{~N}_{-\mathrm{NH}_{4}}$ in the aerated and non-aerated biofilters, respectively. Whereas phosphorus and nitrate levels were significantly high in the aerated biofilter. There was no significant difference in the growth of fish between the aerated and non-aerated biofilters. The results suggest that non-aerated biofilters can be as effective as aerated biofilters in maintaining suitable water quality for O. niloticus production.
\end{abstract}

Keywords: Aerated, denitrification, nitrification, non-aerated, removal efficiency

\section{Zusammenfassung}

Beim Großteil geschlossener Kreislaufanlagen (RAS) kommen aerobe Biofilter zum Einsatz, um eine ausreichend gute Wasserqualität für die Fischproduktion zu gewährleisten. Die Anwendung anaerober Biofilter bietet jedoch Vorteile, wie die Reduktion von Belüftungskosten und Wasserverbrauch sowie die Erhöhung der Stickstoffkonzentration im Abwasser. Das Ziel dieser Studie ist der gleichzeitige Vergleich belüfteter und unbelüfteter Biofilter innerhalb eines geschlossenen Kreislaufsystems. Die beiden Filtersysteme wurden in dreifacher Wiederholung getestet und waren durchgehend sieben Monate im Einsatz. Wasserparameter wurden sowohl im Zu- und Ablauf des jeweiligen Filtersystems gemessen als auch in den zugehörigen Fischbehältern. Am Beginn des Versuchs konnten keine signifikanten Unterschiede in der Ammoniak-Konzentration festgestellt werden. Die Konzentrationen nahmen jedoch mit der Zeit ab, bis schließlich Werte um $1,33 \pm 0,02 \mathrm{mg} \mathrm{L}^{-1} \mathrm{im}$ aeroben und $1,23 \pm 0,21 \mathrm{mg} \mathrm{L}^{-1} \mathrm{~N}_{-N \mathrm{NH}_{4}}$ im anaeroben Filtersystem erreicht waren. Die Phosphor- und Nitrat-Werte waren hingegen im aeroben Filter signifikant erhöht. Beim Fischwachstum wurde im Vergleich der beiden Filtersysteme jedoch keine signifikanten Unterschiede festgestellt. Die Ergebnisse aus dieser Studie lassen darauf schließen, dass in geschlossenen Kreislaufanlagen die Wasserqualität sowohl durch anaerobe Biofilter als auch durch aerobe Biofilter für O. niloticus ausreichend hoch ist.

Schlagworte: Belüftung, Denitrifikation, Nitrifikation, anaerob, Wirkungsgrad 


\section{Introduction}

The global capture fisheries production has stagnated since 1980 s, and in 2016, the total capture fisheries production was 90.9 million tons, representing a decrease of almost 2 million tons from 92.7 million tons in 2015. At the same time, there has been an increasing global demand for fish (FAO, 2018). FAO estimates indicate an average annual increase in global fish consumption of 3.2\% between 1961 and 2016 (FAO, 2018). The expansion of aquaculture sector will probably provide a solution to the stagnating capture fisheries and meet the demand for fish (Waite et al., 2014). However, common aquaculture production systems such as ponds may not contribute significantly to aquaculture production because they require more land as well as large volumes of water for expansion (Verdegem et al., 2006). Therefore, to meet the increasing global demand for fish, aquaculture production must be intensified to minimize reliance on limited land and water resources (Waite et al., 2014). However, pond-based systems allow limited options for intensification. Besides, the systems are operated in a flow-through system where water is frequently exchanged with fresh water from adjacent rivers to maintain water quality for fish production (Liti et al., 2005). The discharge of untreated aquaculture wastewater contaminates the quality of water of the receiving aquatic ecosystems (Ramírez-Godínez et al., 2013; Turcios and Papenbrock, 2014).

Recirculating aquaculture systems are recognized as suitable systems that can increase production, minimize wastewater discharge as well as reliance on limited land and freshwater resources (Badiola et al., 2012). Removal of waste in these systems is generally managed through mechanical removal of solids and conversion of ammonia and nitrite to nitrate through the nitrification process (Hamlin et al., 2008). But, nitrification does not result in the overall reduction of nitrogenous wastes but merely transforms ammonia to nitrate, resulting in nitrate accumulation and lowering of the $\mathrm{pH}$ of culture water (Piedrahita, 2003). Therefore, RAS requires $10-20 \%$ of water exchange each day to reduce accumulation of nitrates and maintain suitable water quality for fish (Martins et al., 2010). Such water exchange increases water consumption and the cost of fish production (Meriac, 2014). Besides, water exchange is undesirable due to the potential negative impact on the cultured fish and the recipient environment (Davidson et al., 2009). Davidson et al. (2014) demonstrated that high nitrate concentrations in RAS with minimal water exchange can cause chronic toxicity to fish. Further, the nitrifying bacteria have long start-up and multiplication periods and require high oxygen concentrations which translates to higher energy costs (Delong and Losordo, 2012; Cristian et al., 2013). The bacteria are also sensitive to rapid changes in $\mathrm{pH}$, temperature and water flow and take longer to recover in the event of system failure (Lee et al., 2000).

Furthermore, one of the major constraints to the widespread of RAS, particularly in the Sub-Saharan African countries such as Kenya, is the high energy costs connected to its operation (Opiyo et al., 2018). Hence, there is a need for systems that can lower energy costs, improve productivity and efficiency. For this reason, current technical innovations in RAS are searching for more energy and cost-efficient systems such as the incorporation of denitrification biofilter in freshwater RAS to reduce the operating costs by 10\% (Martins et al., 2010). Denitrification reduces inorganic nitrogen compounds such as nitrite and nitrate to elemental nitrogen and can provide solutions to the limitations of nitrification (Gichana at al., 2018). Facultative anoxic bacteria fuel the process with electron donors from either organic or inorganic sources (van Rijn et al., 2006). The anoxic bacteria are most abundant in the aquatic environment (Dalsgaard et al., 2003) and have higher growth rates of 4.8 day $^{-1}$ than that of the nitrifying bacteria having growth rate of $0.76-0.84$ day $^{-1}$ (Fdz-Polanco et al., 2000). Moreover, denitrification reduces water exchange requirements and power consumption (van Rijn et al., 2006). Integrating denitrification in RAS reduces waste discharge by $81 \%$ for nitrogen, $59 \%$ for chemical oxygen demand, $61 \%$ for total oxygen demand, $58 \%$ for total solids and $30 \%$ for carbon dioxide (Martins et al., 2010). Despite the considerable advantages of introducing denitrification in recirculating systems, its use in commercial aquaculture is still limited and the aquaculture industry has been slow to adopt this technology. Major reasons include: (1) the requirement to circulate water through aerobic biofilters, (2) the need for skilled personnel for operation and maintenance, and (3) the alternative use of a costly external carbon source (van Rijn et al., 2006; Martins et al., 2010).

Studies evaluating biofilter performances are becoming more common in RAS, but most of these studies are done at laboratory or on pilot scale. Assessment of biofilters in the actual culture conditions is urgently needed (Guerdat, 2008). Furthermore, most denitrification studies use nitrifying biofilter before the denitrifying biofilter to convert ammonia to nitrates, which is thereafter converted into 
elemental nitrogen in the denitrification chamber. Studies incorporating nitrification and denitrification processes in a single biofilter are few or non-existent. The aim of our study was to: (1) design a single biofilter that requires very low maintenance and incorporates nitrification and denitrification processes, (2) compare the biofiltration efficiency of the non-conventional non-aerated biofilter and the conventional aerated biofilter and (3) evaluate the effect of the two biofilters on the growth of $O$. niloticus. This study was motivated by the fact that different nitrogen cycling bacteria including nitrifiers and denitrifiers coexist in a biofilm as long as conditions that favor their growth are created (Egli et al., 2003; van Kessel et al., 2010).

\section{Materials and methods}

\subsection{Experimental design}

The experiment was conducted for seven months from March to October 2017 at Aqualife Fish Farm, Machakos County, Kenya. The effects of two types of biofilters, aerated and non-aerated on water quality and fish performance in a RAS stocked with $O$. niloticus were tested. The two biofilters were used as treatments, and each treatment was replicated three times. The biofilters represented a conventional aerated biofilter, which was used as a control and a non-aerated biofilter as the test treatment. Before the start of the experiment, the cold start method was used to activate the biofilters. The method involves stocking of fish and allowing bacteria to colonize the biofilter substrates naturally (Delong and Losordo, 2012).

\subsection{Recirculation aquaculture unit}

Two identical recirculating aquaculture systems (RAS_1 with aerated biofilter and RAS_2 with non-aerated biofilter) were installed under a greenhouse. Each RAS consisted of nine circular indoor fish tanks $\left(0.5 \mathrm{~m}^{3}\right.$ each), containing $7,200 \mathrm{~m}^{3}$ of the total recirculating water. The system included a $0.5 \mathrm{~m}^{3}$ sump, 2, $0.21 \mathrm{~m}^{3}$ sand filters and a biofiltration unit. The effluent from fish tanks of each system was combined and channeled into sand filters before discharging into a common sump (Figure 1). Water from the common sump with similar physical and chemical characteristics was then pumped to the two biofilters using two pumps (0.5 HP, 8000L hr-1, $370 \mathrm{~W}$, Davis and Shirtliff). An air pump (Aqua Forte, V-60) with a pressure of $>0.03$
Mpa and output $60 \mathrm{~L} \mathrm{~min}^{-1}$ supplied air in the rearing tanks and in the aerated biofilter through a network of air stones and porous disc diffusers respectively.

The filtered water from the biofilters was then channeled by gravity back to the fish tanks in three replicates. However, the effluent from the non-aerated biofilters was aerated before flowing into the fish tanks to provide optimum oxygen for fish. Fifty $O$. niloticus juveniles with an average weight of $50 \mathrm{~g}$ were stocked in each fish tank. The fish were hand fed twice a day (09:00 h and 16:00 h) to satiation with a $30 \%$ crude protein diet. The stocked fish were sampled at two-weeks intervals and their weight and length measured using a digital balance with a $0.1 \mathrm{~g}$ precision and a measuring board respectively. The performance of fish was evaluated using growth parameters such as weight gain, Feed Conversion Ratio (FCR), \% Survival and Specific Growth Rate (SGR). The growth parameters were calculated using the following standard formulae (1-4).

Weight gain $(\mathrm{g})$ = Final weight $(\mathrm{g})$ - initial weight $(\mathrm{g})$

$$
\text { FCR } \frac{\text { (Total weight of dry feed given }(\mathrm{g}) \text { ) }}{\text { (Total wet weight gain }(\mathrm{g}))}
$$

Survival rate $=\frac{\mathrm{N}_{0}-\mathrm{N}_{\mathrm{t}}}{\mathrm{N}_{0}} \times 100$

$\operatorname{SGR}\left(\%\right.$ day $\left.^{-1}\right)=\left(\ln \mathrm{W}_{\mathrm{f}}-\ln \mathrm{W}_{\mathrm{i}}\right) / \mathrm{t} \times 100$

where $\mathrm{W}_{\mathrm{i}}$ and $\mathrm{W}_{\mathrm{f}}$ are initial and final mean wet weight in $\mathrm{g}$, respectively; $\ln =$ natural $\log$ arithm; $\mathrm{t}=$ time in days $\mathrm{N}_{0}$ and $\mathrm{N}_{\mathrm{t}}$ are fish number at time 0 and at time $\mathrm{t}$, respectively.

\subsection{Biofilter units}

A raised wooden platform was used to hold the biofilters and allow the effluent to flow by gravity to the fish tanks. Each biofilter consisted of $0.21 \mathrm{~m}^{3}$ plastic barrels arranged in series, and each biofilter series consisted of three plastic barrels making a total of nine barrels per biofilter. The aerated biofilters were aerated using porous disc diffusers located at the bottom of the biofilter, while the non-aerated biofilters were not aerated. The aerated biofilters and porous disc diffusers were subjected to biweekly cleaning to reduce fine solid accumulation. Non-aerated biofilters were not subjected to cleaning to allow fine solid accumulation, which encourages the growth of denitrifying bacteria. Locally available and low-cost pumice stones 


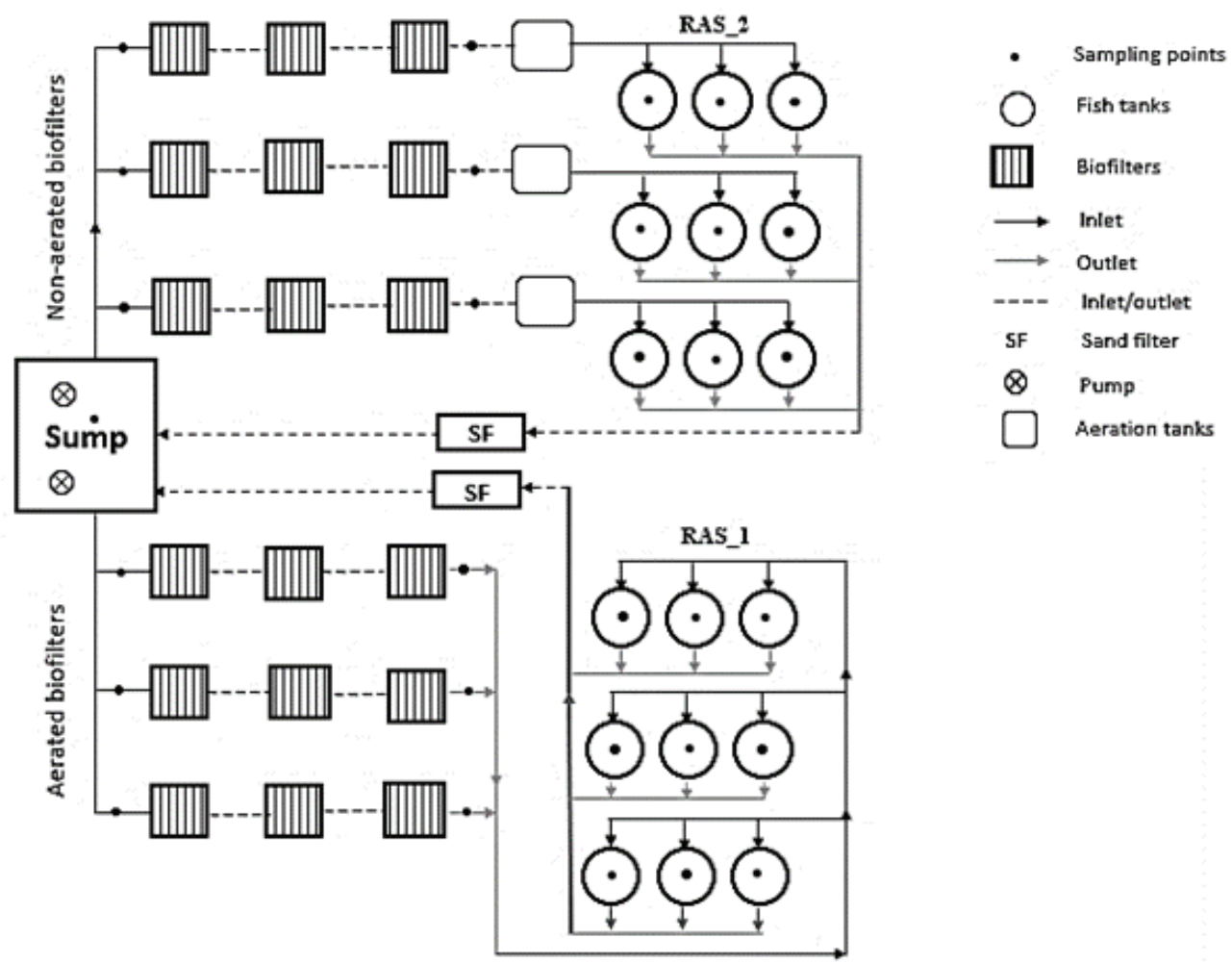

Figure 1. An illustration of the recirculating aquaculture systems with the aerated and non-aerated biofilters. Arrows indicate the direction of water flow. Abbildung 1. Darstellung der geschlossenen Kreislaufanlage mit den aeroben und anaeroben Biofiltern. Die Pfeile stellen die Fließrichtung des Wassers dar.

(porous volcanic granules) were used as biofilter substrate. The plastic barrels were filled with thoroughly rinsed and sundried pumice granules $(-2-3 \mathrm{~mm}$ grain size) to a height of $0.55 \mathrm{~m}$ taking a volume of $0.15 \mathrm{~m}^{3}$. The biofilters were operated in an up-flow mode where water was pumped to the bottom of the barrel. A constant flow rate of $2.3 \mathrm{~L}$ $\min ^{-1}$ was maintained in the biofilter inlets. The flow rate was controlled with ball type valves.

\subsection{Water quality parameters and analysis}

Water samples were collected biweekly from the inlet and outlet of the two biofilters and fish tanks. On the day of collection, the samples were analyzed for ammonium, nitrate, nitrite, phosphorus and alkalinity using benchtop Hanna multiparameter photometer (HI83200) based on Nessler, cadmium reduction, diazotization, ascorbic acid and titration with sulphuric acid and methyl orange indicator methods respectively (APHA, 2005). Temperature, $\mathrm{pH}$, dissolved oxygen and conductivity were measured in situ twice daily in the sump, fish tanks as well as at the outlet and inlet of the aerated and non-aerated biofilters using $\mathrm{HACH}$ probes (HACH HQ40d Portable meter, USA). The flow rate was measured from the inlet pipe by determining the time it takes to fill a container of known volume. The nutrient removal efficiency of the biofilters was calculated using the following formula (Christianson et al., 2015):

$$
\text { Removal efficiency (\%) } \frac{C_{i}-C_{e}}{C_{i}} \times 100
$$

where $\mathrm{C}_{\mathrm{i}}=$ concentration of inlet and $\mathrm{C}_{\mathrm{e}}=$ concentration of outlet.

\subsection{Data analysis}

Mean values for physical and chemical variables and fish growth parameters were calculated. Normality and homogeneity of means were evaluated by Shapiro-Wilks and Levene tests respectively (Zar, 2010). Percentage data were subjected to arcsine transformation before statistical analyses. The relationship between fish growth and physical-chemical water variables was determined using 
Table 1. Water quality parameters in the sump (fish tanks outlet/biofilter inlet) and aerated and non-aerated biofilter outlets. Mean values ( \pm standard deviations) within a row with different superscripts are significantly different $(\mathrm{a}>\mathrm{b}>\mathrm{c}, \mathrm{p}<0.05)$.

Tabelle 1. Wasserparameter im Sammelbehälter (Übergangsbereich vom Fischtanks zum Biofilter) sowie jeweils am Ende der aeroben und anaeroben Biofilterkette. Mittelwerte ( \pm Standardabweichung) innerhalb einer Zeile mit unterschiedlichen Hochzahlen unterscheiden sich statistisch signifikant $(\mathrm{a}>\mathrm{b}>\mathrm{c}, \mathrm{p}<0,05)$.

\begin{tabular}{lcccc}
\hline Parameters & Units & Sump & Aerated biofilters & Non-aerated biofilters \\
\hline Temperature & {$\left[{ }^{\circ} \mathrm{C}\right]$} & $25.18 \pm 1.48^{\mathrm{a}}$ & $25.37 \pm 1.70^{\mathrm{a}}$ & $25.50 \pm 1.92^{\mathrm{a}}$ \\
$\mathrm{pH}$ & & $7.81 \pm 0.11^{\mathrm{b}}$ & $7.78 \pm 0.09^{\mathrm{b}}$ & $7.70 \pm 0.09^{\mathrm{a}}$ \\
Dissolved oxygen & {$\left[\mathrm{mg} \mathrm{L}^{-1}\right]$} & $2.89 \pm 0.41^{\mathrm{c}}$ & $2.11 \pm 0.77^{\mathrm{b}}$ & $1.45 \pm 0.39^{\mathrm{a}}$ \\
Alkalinity & {$\left[\mathrm{mg} \mathrm{L}^{-1}\right]$} & $242.69 \pm 32.83^{\mathrm{a}}$ & $216.79 \pm 46.93^{\mathrm{a}}$ & $234.23 \pm 56.13^{\mathrm{a}}$ \\
Ammonia & {$\left[\mathrm{mg} \mathrm{NH}_{3}-\mathrm{N} \mathrm{L}^{-1}\right]$} & $3.41 \pm 0.39^{\mathrm{b}}$ & $1.96 \pm 0.60^{\mathrm{a}}$ & $1.95 \pm 0.65^{\mathrm{a}}$ \\
Nitrates & {$\left[\mathrm{mg} \mathrm{NO}_{3}-\mathrm{N} \mathrm{L}^{-1}\right]$} & $2.49 \pm 0.60^{\mathrm{b}}$ & $3.16 \pm 0.74^{\mathrm{c}}$ & $1.47 \pm 0.89^{\mathrm{a}}$ \\
Nitrites & {$\left[\mathrm{mg} \mathrm{NO}_{2}-\mathrm{N} \mathrm{L}^{-1}\right]$} & $0.36 \pm 0.16^{\mathrm{a}}$ & $0.55 \pm 0.15^{\mathrm{a}}$ & $0.18 \pm 0.07^{\mathrm{a}}$ \\
Phosphorus & {$\left[\mathrm{mg} \mathrm{L}^{-1}\right]$} & $2.14 \pm 1.15^{\mathrm{b}}$ & $1.71 \pm 1.25^{\mathrm{ab}}$ & $1.22 \pm 0.78^{\mathrm{a}}$ \\
\hline
\end{tabular}

multiple regression (Statgraphics ${ }^{\oplus}$ version 16.1.11, StatPoint Technologies, Inc, USA.). One-way analysis of variance (ANOVA) was used to determine the differences in physical-chemical parameters between the sump, aerated and non-aerated biofilter outlets. Tukey post hoc test was performed when necessary to determine the specific significant differences between means. Student t-test was used to test significant differences in nutrient removal efficiency and the growth of fish between the aerated and non-aerated biofilters (SPSS for Windows, Version 21.0, IBM, Armonk, NY, USA). Differences between means were considered significant at $\mathrm{p}<0.05$.

\section{Results}

\subsection{Water quality}

Ammonia and dissolved oxygen levels were significantly higher in the sump (fish tank outlets/biofilter inlet) $(\mathrm{p}<0.05)$ than in the aerated and non-aerated biofilter outlets (Table 1).

However, there were no significant differences in temperature, alkalinity, and nitrite between the water in the sump and biofilters. Moreover, no significant differences in ammonia levels were observed between the aerated and non-aerated biofilters. Phosphorus, dissolved oxygen, $\mathrm{pH}$ and nitrate levels were significantly lower at the non-aerated biofilter outlets $(\mathrm{p}<0.05)$ than those at the aerated biofilter outlets.
There were no significant differences in the water quality parameters between RAS_1 and RAS_2. Temperature ranged between $22.55^{\circ} \mathrm{C}$ and $29.97^{\circ} \mathrm{C}$ in the two recirculating systems. The average $\mathrm{pH}$ was alkaline (7.7) and maintained between 6.9 and 8.1 in all the fish tanks. Dissolved oxygen (DO) values ranged between 1.1 to $4.1 \mathrm{mg} \mathrm{L}^{-1}$ and alkalinity values were always above $160 \mathrm{mg} \mathrm{L}^{-1}$ during the experiment. Ammonia, nitrate, nitrite and phosphorus concentrations were comparable in the two systems (Table 2).

\subsection{Performance of biofilters}

The performance of the biofilters was determined by measuring the levels of ammonia, nitrate, nitrite concentrations at the inlet and outlet of the biofilters (Figure 2). Significant differences $(\mathrm{p}<0.05)$ between biofilter inlets and outlets were observed in all nutrient concentrations except nitrites. Ammonia concentration at the inlet to the biofilters was significantly $(\mathrm{p}<0.05)$ higher than at the aerated and non-aerated biofilter outlets.

The concentration of nitrate was relatively stable throughout the sampling period. However, the aerated biofilter had higher concentrations than the non-aerated biofilter. Nitrite levels were also relatively stable with lower levels at the biofilter outlets compared to the inlets. Phosphorus concentrations increased with time during the experimental period at the biofilter inlets with the peak at the end of the experiment. The concentration of phosphorus was significantly lower in non-aerated biofilter than in the aerated biofilters $(\mathrm{p}<0.05)$. 
Table 2. Water quality parameters in the fish tanks (Mean \pm standard deviation)

Tabelle 2. Wasserparameter in den Fischtanks (Mittelwerte \pm Standardabweichung)

\begin{tabular}{lccc}
\hline Parameters & Units & RAS_1 & RAS_2 \\
\hline Temperature & {$\left[{ }^{\circ} \mathrm{C}\right]$} & $26.25 \pm 2.72^{\mathrm{a}}$ & $26.23 \pm 2.67^{\mathrm{a}}$ \\
$\mathrm{pH}$ & & $7.71 \pm 0.19^{\mathrm{a}}$ & $7.72 \pm 0.16^{\mathrm{a}}$ \\
Dissolved oxygen & {$\left[\mathrm{mg} \mathrm{L}^{-1}\right]$} & $2.37 \pm 0.76^{\mathrm{a}}$ & $2.54 \pm 0.79^{\mathrm{a}}$ \\
Alkalinity & {$\left[\mathrm{mg} \mathrm{L}^{-1}\right]$} & $226.28 \pm 36.70^{\mathrm{a}}$ & $223.68 \pm 38.48^{\mathrm{a}}$ \\
Ammonia & {$\left[\mathrm{mg} \mathrm{NH}_{3}-\mathrm{N} \mathrm{L} \mathrm{L}^{-1}\right]$} & $2.43 \pm 0.87^{\mathrm{a}}$ & $2.58 \pm 0.76^{\mathrm{a}}$ \\
Nitrate & {$\left[\mathrm{mg} \mathrm{NO}_{3}-\mathrm{N} \mathrm{L}^{-1}\right]$} & $2.92 \pm 1.63^{\mathrm{a}}$ & $2.76 \pm 1.54^{\mathrm{a}}$ \\
Nitrite & {$\left[\mathrm{mg} \mathrm{NO}_{2^{-}}-\mathrm{N} \mathrm{L}^{-1}\right]$} & $0.26 \pm 0.18^{\mathrm{a}}$ & $0.24 \pm 0.08^{\mathrm{a}}$ \\
Phosphorus & {$\left[\mathrm{mg} \mathrm{L}^{-1}\right]$} & $1.48 \pm 1.08^{\mathrm{a}}$ & $1.57 \pm 1.06^{\mathrm{a}}$ \\
\hline
\end{tabular}

The removal efficiency of nitrate $(\mathrm{t}(76)=10.5, \mathrm{p}=0.00)$ and phosphorus $(\mathrm{t}(76)=3.4, \mathrm{p}=0.001)$ was significantly higher in the non-aerated biofilters than in the aerated biofilters (Figure 3). Ammonia removal efficiency was similar in the aerated biofilters $(37.71 \pm 11.8 \%)$ and non-aerated biofilters $(41.90 \pm 15.8 \%)$. However, nitrate removal efficiency was negative in the aerated $(-26.3 \pm 14.0 \%)$ and significantly high $(\mathrm{p}<0.05)$ in the non-aerated biofilters $(39.7 \pm 32.3 \%)$. There was no significant difference in the removal of nitrite between the aerated and non-aerated biofilters. Phosphorus removal was high in the non-aerated biofilters $(45.65 \pm 19.5 \%)$ compared to the aerated biofilters $(24.82 \pm 27.4 \%)$.
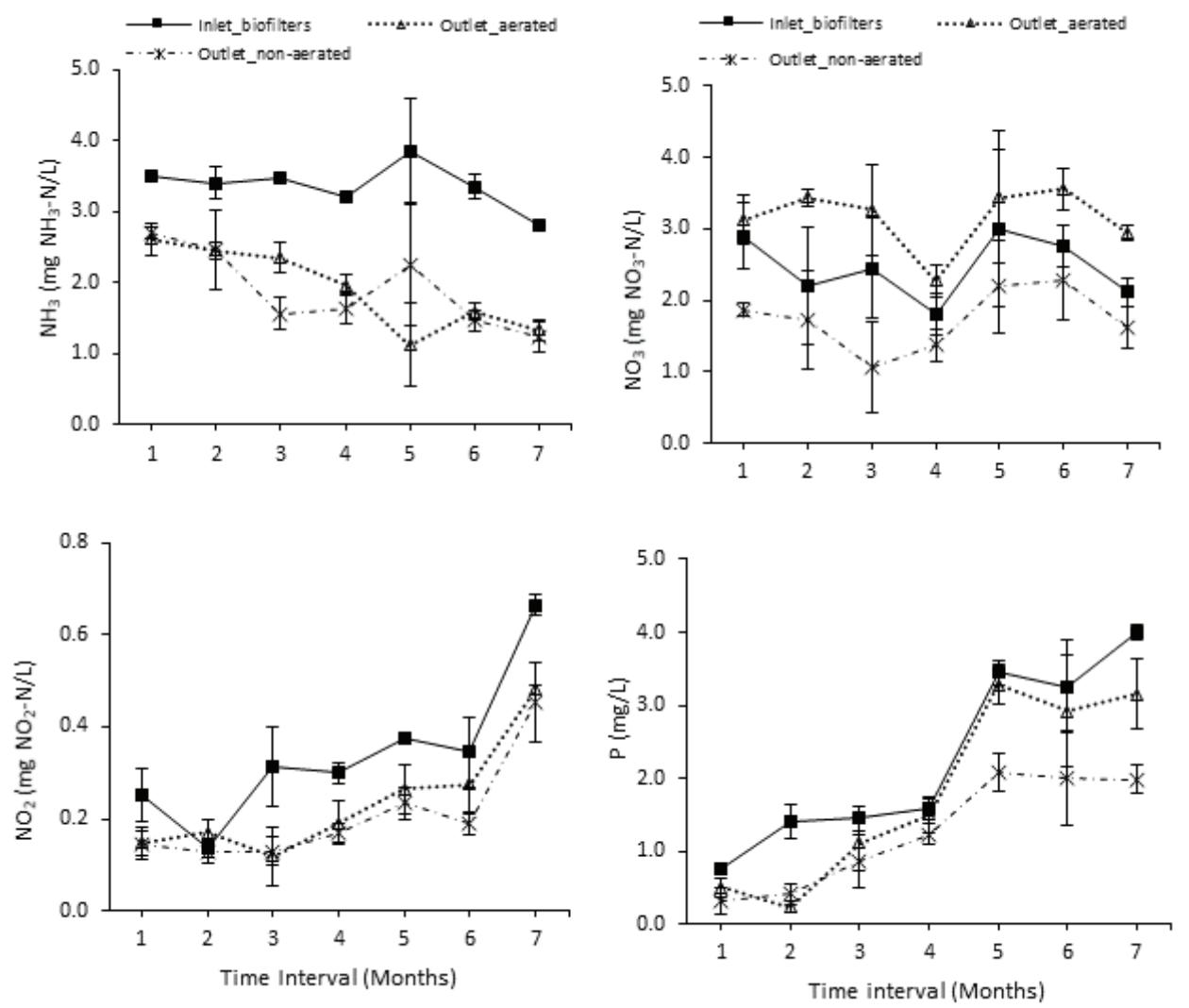

Figure 2. Ammonia $\left(\mathrm{NH}_{3}-\mathrm{N}\right)$, nitrates $\left(\mathrm{NO}_{3}-\mathrm{N}\right)$, nitrites $\left(\mathrm{NO}_{2}-\mathrm{N}\right)$ and $\mathrm{P}$ (phosphorus) concentrations in the aerated and non-aerated biofilters. Error bars show standard deviations $(\mathrm{n}=3)$.

Abbildung 2. Konzentrationen von Ammoniak $\left(\mathrm{NH}_{3}-\mathrm{N}\right)$, Nitrat $\left(\mathrm{NO}_{3}-\mathrm{N}\right)$, Nitrit $\left(\mathrm{NO}_{2}-\mathrm{N}\right)$ und Phosphor $(\mathrm{P})$ in den aeroben und anaeroben Biofiltern. Die Fehlerbalken stellen die Standardabweichungen dar $(\mathrm{n}=3)$. 
Table 3. Growth performance of $O$. niloticus in the recirculation aquaculture systems with aerated and non-aerated treatments. All values are means \pm standard deviations obtained from three replicates.

Tabelle 3. Wachstumsentwicklung von O. niloticus in der Kreislaufanlage mit aeroben und anaeroben Filtern. Alle Werte stellen Mittelwerte \pm Standardabweichungen aus den drei Wiederholungen dar.

\begin{tabular}{lccc}
\hline & & & Treatments \\
Parameters & Units & Aerated biofilter & Non-aerated biofilter \\
\hline Initial Mean Weight & {$[\mathrm{g}]$} & $54.5 \pm 4.7^{\mathrm{a}}$ & $56.2 \pm 2.7^{\mathrm{a}}$ \\
Final Mean Weight & {$[\mathrm{g}]$} & $132.0 \pm 18.0^{\mathrm{a}}$ & $129.8 \pm 12.8^{\mathrm{a}}$ \\
Weight gain & {$[\mathrm{g}]$} & $77.5 \pm 17.2^{\mathrm{a}}$ & $73.6 \pm 12.5^{\mathrm{a}}$ \\
Specific growth rate & {$\left[\% \mathrm{day}^{-1}\right]$} & $0.42 \pm 0.07^{\mathrm{a}}$ & $0.38 \pm 0.07^{\mathrm{a}}$ \\
Final density & {$\left[\mathrm{kg} \mathrm{m}^{-3}\right]$} & $12.76 \pm 2.45^{\mathrm{a}}$ & $12.84 \pm 1.36^{\mathrm{a}}$ \\
Feed conversion ratio & & $2.67 \pm 0.62^{\mathrm{a}}$ & $3.04 \pm 0.65^{\mathrm{a}}$ \\
Survival rate & {$[\%]$} & $95.6 \pm 4.44^{\mathrm{a}}$ & $93.3 \pm 4.24^{\mathrm{a}}$ \\
\hline
\end{tabular}

\subsection{Growth performance}

The growth performance of $O$. niloticus cultured in recirculation aquaculture systems with aerated and non-aerated biofilter treatments is shown in Table 3 .

No significant differences ( $p>0.05$ ) were observed between the two biofilter treatments in the final mean weight, FCR, weight gain, \% survival, final density and specific growth rate.

\section{Discussion}

Water temperature in the RAS was within acceptable ranges for the growth of nitrifiers (Chen et al., 2006), denitrifiers (Wang and Chu, 2016) and tilapia (Guerdat et al., 2010). The average $\mathrm{pH}$ in the two biofilters was also within the optimum range for the biofiltration process (6.7-9.0) (Chen et al., 2006), the survival and growth of tilapia (Delong et al., 2009). In any aquaculture system, dissolved oxygen is one of the most critical parameters that maintain safe limits and provide optimal growth conditions for the fish (Timmons et al., 2002). Mean dissolved oxygen was lower than preferred $5 \mathrm{mg} \mathrm{L}^{-1}$ for optimum growth of tilapia (Colt, 2006) and within acceptable limits for nitrification (>1.0 $\mathrm{mg} \mathrm{L}^{-1}$ ) (Timmons and Ebeling, 2010). But tilapia can tolerate oxygen concentrations as low as $1.0 \mathrm{mg} \mathrm{L}^{-1}$, and below this level, fish may utilize atmospheric oxygen from the surface film of water (Ross, 2000). Oxygen is also one of the major factors that affect the rate of nitrification in aerated biofilters because nitrifiers are obligate aerobes, which require oxygen to survive and multiply (Timmons and Ebeling, 2010). Low oxygen levels decrease the rate of nitrification, though levels as low as $2 \mathrm{mg} \mathrm{L}^{-1}$ are sufficient to maintain nitrification, while levels below $2 \mathrm{mg} \mathrm{L}^{-1}$ inhibits the process (Timmons and Ebeling, 2010). Non-aerated biofilters depend on facultative anaerobes to convert ammonia or nitrates and nitrites to dinitrogen gas (van Rijn et al., 2006). Therefore, DO of approximately $0.5 \mathrm{mg} \mathrm{L}^{-1}$ or less can allow non-aerated biofiltration in both freshwater and marine systems (van Rijn et al., 2006). Conversely, denitrification can occur in aerated conditions with DO levels as high as $4-5 \mathrm{mg} \mathrm{L}^{-1}$. However, the rate of denitrification decreases in aerated conditions (Gutierrez-Wing et al., 2012).

The high ammonia levels at the beginning of the study suggest that biofilters had not appropriately established. Delong and Losordo (2012) stated that the bacteria responsible for biofiltration take an extended period to grow and multiply. Our findings are consistent with Wongkiew et al. (2017), who reported a build-up of ammonia concentrations during the start-up periods in a recirculating aquaculture system. The consistent low and high nitrate concentration in the non-aerated and aerated biofilter outlets is an indication of nitrate removal and production through denitrification and nitrification processes. High nitrite concentration in the aerated biofilters indicates a higher rate of ammonia oxidation than nitrite oxidation. The high rate of oxidation is due to the shorter generation times of ammonia oxidizing bacteria which increases the growth of more ammonia oxidizing bacteria compared to nitrite oxidizing bacteria and subsequent accumulation of nitrite (Wongkiew et al., 2017). Accumulation of nitrites in the non-aerated biofilters can be attributed to 

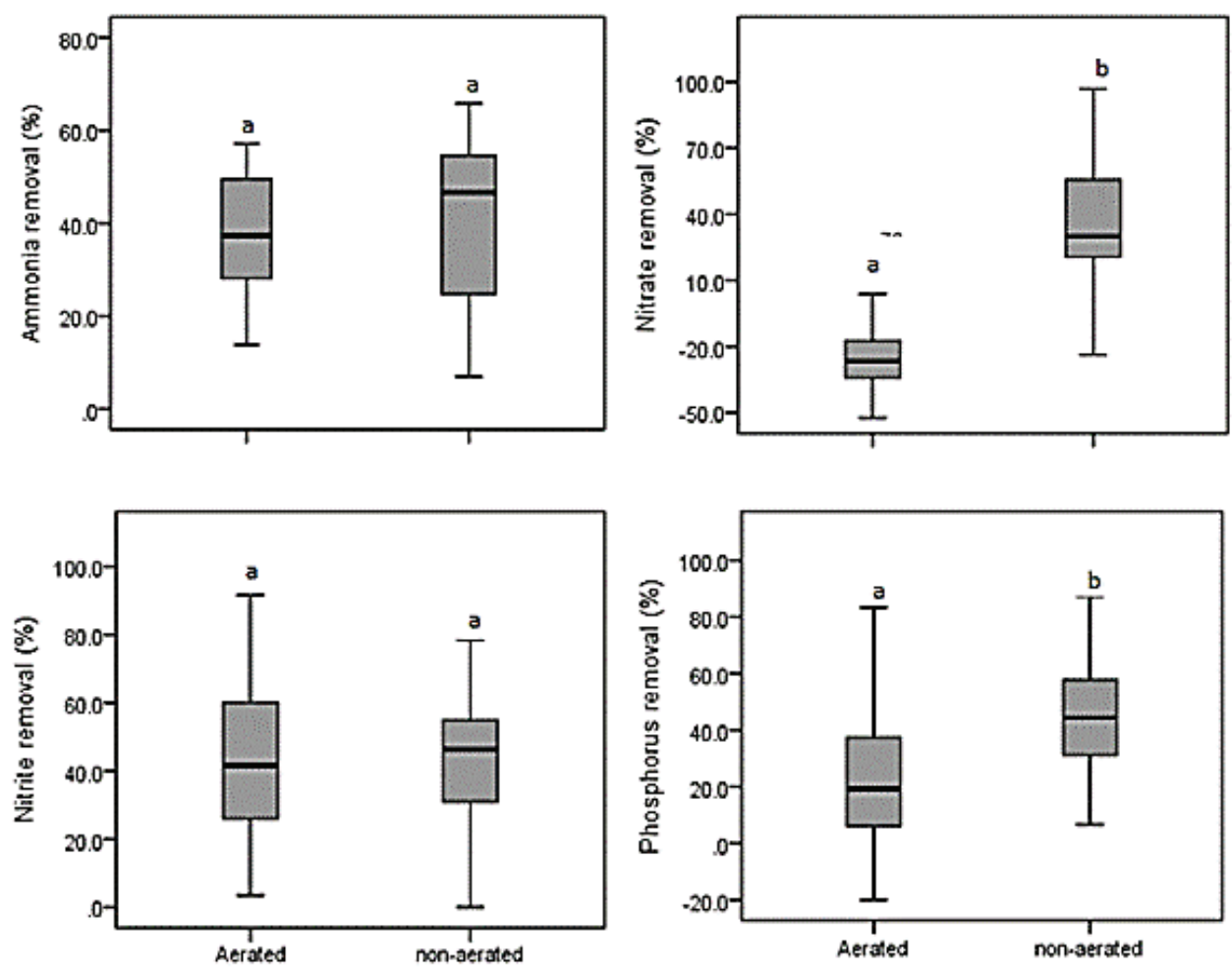

Figure 3. Boxplot showing nutrient removal efficiencies in aerated and non-aerated biofilters. Median values are shown in each box, vertical bars correspond to maximum and minimum values. Different letters $(\mathrm{a}, \mathrm{b})$ above boxplots indicate significant differences between the two types of biofilters (Student $\mathrm{t}$-test) $(\mathrm{p}<0.05)$.

Abbildung 3. Boxplotdarstellung der Nährstoffreduktion in den aeroben und anaeroben Biofiltern. Unterschiedliche Buchstaben bei den jeweiligen Boxplots zeigen signifikante Unterschiede zwischen den beiden Filtertypen (Student t-test) $(p<0,05)$.

incomplete denitrification process, which reduces nitrates to nitrites with no further reduction (Stief, 2001). Ramdhani and Bux (2007) showed that incomplete denitrifiers dominate the denitrifying biofilter and are therefore significantly involved in nitrogen removal during wastewater treatment.

The difference in ammonia removal efficiency between aerated and non-aerated biofilters can be an indication of different biological processes that occurred in the biofilters because of different environmental conditions. Ammonia removal is a function of the ammonia oxidizing bacteria in aerobic and anaerobic conditions (Malone and Pfeiffer, 2006). Under aerobic conditions, ammonia-oxidizing bacteria converts ammonia to nitrates resulting in low ammonia and high nitrate levels in aerated biofilters. Whereas, under anaerobic conditions, anaerobic oxidation of ammonia (anammox) oxidizes ammonia to molecular nitrogen (van Kessel et al., 2010). This can explain the removal of ammonia in the non-aerated biofilter. The ammonia removal efficiency of $37.7 \%$ is within the range (11-80\%) reported by previous studies using nitrifying or nitrifying- denitrifying biofilters in RAS (Kir, 2009; Nootong and Powtongsook, 2012; Tsukuda et al., 2015). Besides, fine solid accumulation and low oxygen levels in the nonaerated biofilter probably favored the denitrification process because low oxygen levels make denitrifying bacteria more competitive than nitrifying bacteria (Bartelme et al., 2017). Denitrification reduces oxidized inorganic nitrogen compounds such as nitrites and nitrates to elemental nitrogen under anaerobic and anoxic conditions using carbon as an electron donor (van Rijn et al., 2006). Therefore, the denitrification process contributed to the significant removal of nitrates in the non-aerated biofilter. Moreover, the significant removal of phosphorus in the non-aerated biofilter can be attributed to denitrification. Studies have shown that some denitrifiers can uptake more phosphorus than their metabolic requirements resulting in low phosphorus in the bioreactor (Krom et al., 2014).

The fish showed poor feed conversion efficiency in both treatments, most probably due to high ammonia concentration. The relatively high ammonia concentration in the culture system might have reduced fish appetite, which 
reduced feed intake and increased FCR values (Effendi et al., 2017). The mean FCR values were higher than the recommended values of $1.5-2.0$ for intensively reared tilapia (Stickney, 2005). The specific growth rates were lower than those from previous studies, which reported growth rates in the range of $0.86 \%$ day $^{-1}$ to $3.09 \%$ day $^{-1}$ in RAS with either aerated and non-aerated biofilters (Shnel et al., 2002; Al-Hafedh and Alam, 2007; Arredondo-Figueroa et al., 2015). The low growth rates in this study were probably due to the long exposure of fish to ammonia concentrations above the acceptable limits of $1.0 \mathrm{mg} \mathrm{L}^{-1}$ (Delong et al., 2009). Furthermore, ammonia and nitrite concentrations had a negative relationship with the weight of fish, suggesting that for every increase in one unit of ammonia and nitrites, there was a corresponding decrease in the growth rate of fish. The survival rates were lower than $97 \%$ obtained by Nootong and Powtongsook (2012) with tilapia grown in a recirculating aquaculture system with submerged fibrous nitrifying biofilters. The final biomass obtained in this experiment was within the range of $12.35-30.35 \mathrm{~kg} \mathrm{~m}^{-3}$ reported by Nootong and Powtongsook (2012). The findings indicate that the non-aerated biofilters did not negatively affect the growth of fish.

\section{Conclusion}

The aerated and non-aerated biofilters reduced wastes generated from the recirculating aquaculture system. Most water quality parameters were within ranges, considered appropriate for fish and biofiltration processes. Although the present study did not use aerated biofilters before the non-aerated biofilters, the latter was able to remove ammonia from the system. Our results demonstrated the feasibility of using non-aerated biofilters to maintain water quality for the production of $O$. niloticus and reduce the discharge of nitrogen and phosphorus wastes to the surrounding environment. Besides, non-aerated biofilters are as effective as aerated ones, suggesting that the non-aerated biofilters can provide opportunities to run the system without the need to reactivate the biofilters in case of system failure. The results also suggest that there is potential to fine-tune biofilter design to take advantage of the coexistence of the nitrification and denitrification bacteria in the biofilters. However, further research is required to fully understand the implications of integrating nitrification and denitrification processes in a single biofilter on nitrogen removal in aquaculture systems.

\section{Acknowledgements}

The study was financed by the Austrian Partnership Programme in Higher Education and Research for Development (APPEAR), a programme of the Austrian Development Cooperation (ADC) and implemented by the Austrian Agency for International Cooperation in Education and Research (OeAD). Special thanks to the "Strengthening Regional Capacity in Research and Training in Fisheries and Aquaculture for Improved Food Security and Livelihoods in Eastern Africa" (STRECAFISH) project, University of Eldoret (Department of biological sciences) for technical and logistical support. We would like to thank anonymous reviewers for their comments and suggestions.

\section{References}

Al-Hafedh, Y.S. and A. Alam (2007): Design and performance of an indigenous water recirculating aquaculture system for intensive production of Nile Tilapia, Oreochromis niloticus (L.), in Saudi Arabia. International Journal of Recirculating Aquaculture 8, 1-20.

APHA (2005): Standard Methods for the Examination of Water and Wastewater. $21^{\text {st }}$ ed., American Public Health Association, Washington, DC.

Arredondo-Figueroa, J.L., Núńez-García, L.G., PoncePalafox, J.T. and I. de Los Ángeles Barriga-Sosa (2015): Performance of Brooders, Fry and Growth of the Nile Tilapia (Oreochromis niloticus) Cultured in an Experimental Recirculating Aquaculture System. Agricultural Sciences 06, 1014-1022.

Badiola, M., Mendiola, D. and J. Bostock (2012): Recirculating Aquaculture Systems (RAS) analysis: Main issues on management and future challenges. Aquacultural Engineering 51, 26-35.

Bartelme, R.P., Mclellan, S.L. and R.J. Newton (2017): Freshwater recirculating aquaculture system operations drive biofilter bacterial community shifts around a stable nitrifying consortium of ammonia-oxidizing Archaea and comammox Nitrospira. Frontiers in Microbiology 8, 101.

Chen, S., Ling, J. and J.P. Blancheton (2006): Nitrification kinetics of biofilm as affected by water quality factors. Aquacultural Engineering 34, 179-197.

Christianson, L., Lepine, C., Tsukuda, S., Saito, K. and S. Summerfelt (2015): Nitrate removal effectiveness of 
fluidized sulfur-based autotrophic denitrification biofilters for recirculating aquaculture systems. Aquacultural Engineering 68, 10-18.

Colt, J. (2006): Water quality requirements for reuse systems. Aquacultural Engineering 34, 143-156.

Cristian, S., Benone, P., Neculai, P., Marilena, T., Victor, C. and T. Magdalena (2013): Preliminary research on the anammox process and control of nitrogen compounds in a recirculating aquaculture system. AACL Bioflux 6, 27-33.

Dalsgaard, T., Canfield, D.E., Petersen, J., Thamdrup, B. and J. Acuña-González (2003): $\mathrm{N}_{2}$ production by the anammox reaction in the anoxic water column of Golfo Dulce, Costa Rica. Nature 422, 606-608.

Davidson, J., Good, C., Welsh, C., Brazil, B. and S. Summerfelt (2009): Heavy metal and waste metabolite accumulation and their potential effect on rainbow trout performance in a replicated water reuse system operated at low or high system flushing rates. Aquacultural Engineering 41, 136-145.

Davidson, J., Good, C., Welsh, C. and S.T. Summerfelt (2014): Comparing the effects of high vs. Low nitrate on the health, performance, and welfare of juvenile rainbow trout Oncorhynchus mykiss within water recirculating aquaculture systems. Aquacultural Engineering 59, 30-40.

Delong, D.P. and T.M. Losordo (2012): How to start a Biofilter. SRAC Publication - Southern Regional Aquaculture Center 3, 1-4.

Delong, D.P., Losordo, T.M. and J.E. Rakocy (2009): Tank culture of tilapia. Southern Regional Aquaculture Center 282.

Effendi, H., Wahyuningsih, S. and Y. Wardiatno (2017): The use of nile tilapia (Oreochromis niloticus) cultivation wastewater for the production of romaine lettuce (Lactuca sativa L. var. longifolia) in water recirculation system. Applied Water Science 7, 3055-3063.

Egli, K., Bosshard, F., Werlen, C., Lais, P., Siegrist, H., Zehnder, A.J.B. and J.R. van der Meer (2003): Microbial composition and structure of a rotating biological contactor biofilm treating ammonium-rich wastewater without organic carbon. Microbial Ecology 45, 419432.

FAO (2018): The State of World Fisheries and Aquaculture 2018 - Meeting the sustainable development goals. Rome, Italy.

Fdz-Polanco, F., Méndez, E., Urueña, M.A., Villaverde, S. and P.A. García (2000): Spatial distribution of hetero- trophs and nitrifiers in a submerged biofilter for nitrification. Water Research 34, 4081-4089.

Gichana, Z.M., Liti, D., Silke, D., Waikibia, J. and H. Waidbacher (2018): Waste management in recirculating aquaculture system through bacteria dissimilation and plant assimilation. Aquaculture International 26, $1541-1572$.

Guerdat, T.C. (2008): A large scale evaluation of commercially available biological filters for recirculating aquaculture systems. Aquacultural Engineering 42, 38-49.

Guerdat, T.C., Losordo, T.M., Classen, J.J., Osborne, J.A. and D.P. DeLong (2010): An evaluation of commercially available biological filters for recirculating aquaculture systems. Aquacultural Engineering 42, 38-49.

Gutierrez-Wing, M., Malone, R. and K. Rusch (2012): Evaluation of polyhydroxybutyrate as a carbon source for recirculating aquaculture water denitrification. Aquacultural Engineering 51, 36-43.

Hamlin, H.J., Michaels, J.T., Beaulaton, C.M., Graham, W.F., Dutt, W., Steinbach, P. and K.L. Main (2008): Comparing denitrification rates and carbon sources in commercial scale upflow denitrification biological filters in aquaculture. Aquacultural Engineering 38, 79-92

Kir, M. (2009): Nitrification performance of a submerged biofilter in a laboratory scale size of the recirculating shrimp system. Turkish Journal of Fisheries and Aquatic Sciences 9, 209-214.

Krom, M.D., Ben David, A., Ingall, E.D., Benning, L.G., Clerici, S., Bottrell, S. and J. van Rijn (2014): Bacterially mediated removal of phosphorus and cycling of nitrate and sulfate in the waste stream of a "zero -discharge" recirculating mariculture system. Water Research 56, 109-121.

Lee, P.G., Lea, R.N., Dohmann, E., Prebilsky, W., Turk, P.E., Ying, H. and J.L. Whitson (2000): Denitrification in aquaculture systems: An example of a fuzzy logic control problem. Aquacultural Engineering 23, 37-59.

Liti, D., Cherop, L., Munguti, J.M. and L. Chhorn (2005): Growth and economic performance of Nile tilapia (Oreochromis niloticus) fed on two formulated diets and two locally available feeds in fertilized ponds. Aquaculture Research 36, 746-752.

Malone, R.F. and T.J. Pfeiffer (2006): Rating fixed film nitrifying biofilters used in recirculating aquaculture systems. Aquacultural Engineering 34, 389-402.

Martins, C.I.M., Eding, E.H., Verdegem, M.C.J., Heinsbroek, L.T.N., Schneider, O., Blancheton, J.P. and J.A.J. Verreth (2010): New developments in recirculat- 
ing aquaculture systems in Europe: A perspective on environmental sustainability. Aquacultural Engineering 43, 83-93.

Meriac, A. (2014): Dietary carbohydrates and denitrification in recirculating aquaculture systems. Wageningen University.

Nootong, K. and S. Powtongsook (2012): Performance evaluation of the compact aquaculture system integrating submerged fibrous nitrifying biofilters. Songklanakarin Journal of Science and Technology 34, 53-59.

Opiyo, M.A., Marijani, E., Muendo, P., Odede, R., Leschen, W. and H. Charo-Karisa (2018): A review of aquaculture production and health management practices of farmed fish in Kenya. International Journal of Veterinary Science and Medicine 6, 141-148.

Piedrahita, R.H. (2003): Reducing the potential environmental impact of tank aquaculture effluents through intensification and recirculation. Aquaculture 226, $35-44$.

Ramdhani, N. and F. Bux (2007): Functional characterization of heterotrophic denitrifying bacteria in activated sludge. South African Journal of Science 103, 113-116.

Ramírez-Godínez, J., Beltrán-Hernández, R.I., CoronelOlivares, C., Contreras-López, E., Quezada-Cruz, M. and G. Vázquez-Rodríguez (2013): Recirculating Systems for Pollution Prevention in Aquaculture Facilities. Journal of Water Resource and Protection 5, 5-9.

Ridha, M. and E.M. Cruz (2001): Effect of biofilter media on water quality and biological performance of the Nile Tilapia Oreochromis niloticus L. reared in a simple recirculation system. Aquacultural Engineering 24, 157166.

Ross, L. (2000): Environmental physiology and energetics. In: Beveridge, M.C.M. and B.J. McAndrew (Eds.): Tilapias: Biology and exploitation. Springer, Dordrecht, pp. 89-128.

Shnel, N., Barak, Y., Ezer, T., Dafni, Z. and J. van Rijn (2002): Design and performance of a zero-discharge tilapia recirculating system. Aquacultural Engineering 26, 191-203.

Stickney, R.R. (2005): Aquaculture: An introduction text. CABI Publishing, Cambridge, USA.

Stief, P. (2001): Influence of sediment and pore-water composition on nitrite accumulation in a nitrate-perfused freshwater sediment. Water Research 35, 2811-2818.

Timmons, M.B. and J.M. Ebeling (2010): Recirculating Aquaculture. Publication No. 401-2010, Northeastern
Regional Aquaculture Center (NRAC), Cayuga Aqua Ventures, Ithaca, New York.

Timmons, M.B., Ebeling, J.M., Wheaton, F.W., Summerfelt, S.T. and B.J. Vinci (2002): Recirculating Aquaculture Systems. Publication No. 01-002, Northeastern Regional Aquaculture Center (NRAC), Cayuga Aqua Ventures, Ithaca, New York.

Tsukuda, S., Christianson, L., Kolb, A., Saito, K. and S. Summerfelt (2015): Heterotrophic denitrification of aquaculture effluent using fluidized sand biofilters. Aquacultural Engineering 64, 49-59.

Turcios, A.E. and J. Papenbrock (2014): Sustainable treatment of aquaculture effluents - What can we learn from the past for the future? Sustainability 6, 836-856.

van Kessel, M.A.H.J., Harhangi, H.R., van de PasSchoonen, K., van de Vossenberg, J., Flik, G., Jetten, M.S.M. and H.J.M. Op den Camp (2010): Biodiversity of $\mathrm{N}$-cycle bacteria in nitrogen removing moving bed biofilters for freshwater recirculating aquaculture systems. Aquaculture 306, 177-184.

van Rijn, J., Tal, Y. and H.J. Schreier (2006): Denitrification in recirculating systems: Theory and applications. Aquacultural Engineering 34, 364-376.

Verdegem, M.C.J., Bosma, R.H. and J.A.J. Verreth (2006): Reducing water use for animal production through aquaculture. International Journal of Water Resources Development 22, 101-113.

Waite, R., Beveridge, M., Brummett, R., Castine, S., Chaiyawannakarn, N., Kaushik, S. and M. Phillips (2014): Improving productivity and environmental performance of aquaculture. Creating a Sustainable Food Future 43, 1-60.

Wang, J. and L.L. Chu (2016): Biological nitrate removal from water and wastewater by solid-phase denitrification process. Biotechnology Advances 34, 1103-1112.

Wongkiew, S., Hu, Z., Chandran, K., Lee, J.W. and S.K. Khanal (2017): Nitrogen transformations in aquaponic systems: A review. Aquacultural Engineering, 76, 9-19.

Zar, J.H. (2010): Biostatistical Analysis. $5^{\text {th }}$ ed., Prentice Hall, New Jersey. 